\title{
CHANGES IN SNOWBED VEGETATION IN THE WESTERN CARPATHIANS UNDER CHANGING CLIMATIC CONDITIONS AND LAND USE IN THE LAST DECADES
}

\author{
ANDREJ PALAJ, JOZEF KOLLÁR \\ Department of Ecology and Environmental Sciences, Faculty of Natural Sciences CPU in Nitra, Trieda A. Hlinku 1, \\ 94974 Nitra, Slovak Republic; e-mail: andrej.palaj@savba.sk \\ Institute of Landscape Ecology, Slovak Academy of Sciences, Štefánikova 3, P.O. Box 254, 81499 Bratislava, Slovak \\ Republic; e-mail: j.kollar@savba.sk
}

\begin{abstract}
Palaj A., Kollár J.: Changes in snowbed vegetation in the Western Carpathians under changing climatic conditions and land use in the last decades. Ekológia (Bratislava), Vol. 38, No. 4, p. 318-335, 2019.

Snowbed vegetation is one of the most sensitive alpine vegetation type to the climate change, because shortened period of snow cover has essential impact on the snowbed environment. We focus on its changes in the Western Tatras, which is a part of the Western Carpathians (Slovakia). The assessment of changes in snowbed vegetation is based on the method of pair comparison. In 2016-2018, we resampled 21 historical phytocoenological relevés of Festucion picturatae and Salicion herbaceae alliances from 1974 and 1976. Historical data include 45 species, while recent data include 50 species. We observed a decrease in the frequency of species characteristic for snowbeds and, on the other hand, an increase in that for strong competitors, especially grasses and small shrubs from adjacent habitats. According to Ellenberg's ecological indices, there is some increase in temperature and decrease in light ecological factors in snowbed habitats. In S. herbaceae data, a statistically significant increase in the average species number was observed with new species that penetrated from the adjacent habitats. Changes in species composition between historical and recent data are confirmed by Non-metric multidimensional scaling (nMDS) ordination diagram. Linear mixed-effect models showed big variability in factors that have impact on phytodiversity; nevertheless, temperature is the most significant factor.
\end{abstract}

Key words: snowbed vegetation, changes, climate, land-use, Western Carpathians.

\section{Introduction}

Alpine vegetation is adapted to the specific natural conditions such as diversified relief and bedrock, resulting in varied soil properties, dynamic meso- and microclimate, and so on. Balance between alpine vegetation and its environment is fragile (Kliment, Valachovič, 2007), and change in environment factors leads to the changes in composition and structure of vegetation species.

Changes in temperature are crucial for alpine vegetation. It is accompanied by migration of vertical plant species (Klanderud, Birks, 2003; Pauli et al., 2007; Wilson, Nilsson, 2009; Grytnes et al., 2014; Kyyak et al., 2014) hand in hand with the increase in plant species 
diversity (Holzinger et al., 2008; Odland et al., 2010; Erschbamer et al., 2011; Kanka et al., 2011; Stöckli et al., 2011; Pauli et al., 2012; Matteodo et al., 2016).

In the European mountains, climate change includes an increase in average annual temperature and a decrease in the precipitation in the form of snow, which result in prolongation of vegetation period (Dye, 2002; Matteodo et al., 2016; Czortek et al., 2018). It promotes migration of eurytopic species from the lower altitudes (Vittoz et al., 2008; Britton et al., 2009; Engler et al., 2011; Palaj, Kollár, 2018). This leads to vegetation homogenization, because expansion of new species upward is accompanied by disappearing of stenotopic species (Jurasinski, Kreyling, 2007; Britton et al., 2009; Erschbamer et al., 2011; Ross et al., 2012; Carbognani et al., 2014; Kobiv, 2018).

Land use change, such as grazing cessation, is another essential driver of plant redistribution. Grazing cessation and climate warming have similar impact on alpine flora, and they operate in synergy (Kobiv, 2017). Grazing abandonment triggers successional changes in few years (Hulme et al., 1999; Velev, Apostolova, 2008), with a decrease in light- and colddemanding species (Klein et al., 2004; Wesełowska, 2009; Vassilev et al., 2011; Matteodo et al., 2013), which are replaced by strong competitors such as grasses and small shrubs (Baur et al., 2007; Kucharzyk, Augustyn, 2010; Vassilev et al., 2011; Kobiv, 2014; Kyyak et al., 2014). Contrary to the climate change, land-use change is often accompanied by diversity decrease (Fabiszewski, Wojtuń, 2001; Baur et al., 2007; Korzeniak, 2016).

Snowbed vegetation is one of the plant communities most sensitive to changes because it includes many ecological specialists (Kliment, Valachovič, 2007). Shortened period of snow cover is followed here by disappearance of small chinophilous and cold-demanding species, which are replaced by strong competitors such as grasses and small shrubs from adjacent communities and lower altitudes (Kobiv, Nesteruk, 2001; Virtanen et al., 2003; Britton et al., 2009; Micu, 2009; Daniëls et al., 2011; Kudo et al., 2011; Kapfer et al., 2012; Elumeeva et al., 2013; Carbognani et al., 2014; Sandvik, Odland, 2014; Kobiv, 2016, 2017; Czortek et al., 2018). As a result, contemporary snowbed communities resemble alpine grassland much more than 50 years ago (Matteodo et al., 2016) and are among the most vulnerable alpine vegetation types.

Therefore, this vegetation type offers a good opportunity to study changes taking place in alpine habitats driven by climate change and grazing cessation. We focused on this topic in the alpine environment in the part of Western Tatras. In 2016-2018, we resampled 21 historical relevés of Festucion picturatae and Salicion herbaceae alliances sampled in 1974-1976. In this article, we examined both qualitative and quantitative changes in species composition, changes in environment indicated by Ellenberg's ecological indices (EIV) (Ellenberg et al., 1992), and impact of those environment changes on the diversity.

\section{Material and methods}

\section{Study area}

The study covers an area of 2,345 ha in the Jamnícka and Račkova valley parts of the Western Tatras Mountains (Fig. 1). This area is formed from granite, migmatite, metamorphic rocks and has numerous mylonite zones in the summit areas (Nemčok, 1994). The highest point is Bystrá peak at 2,248 $\mathrm{m}$ a.s.l., which is also the highest peak in the Western Tatras. The area lies in the cold climate region (Plesník, 1974), and we use climate data from 1966 to 2018 


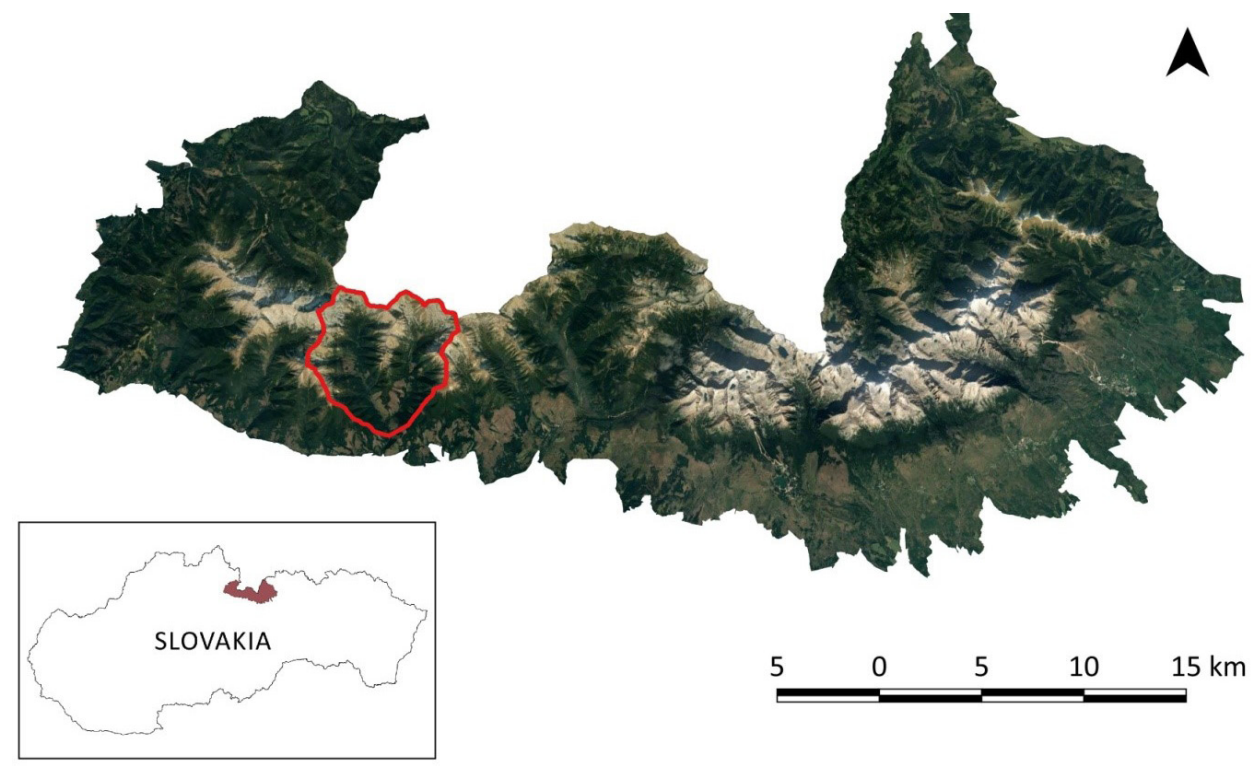

Fig. 1. Location of the study area in the Tatra National Park and in Slovakia.

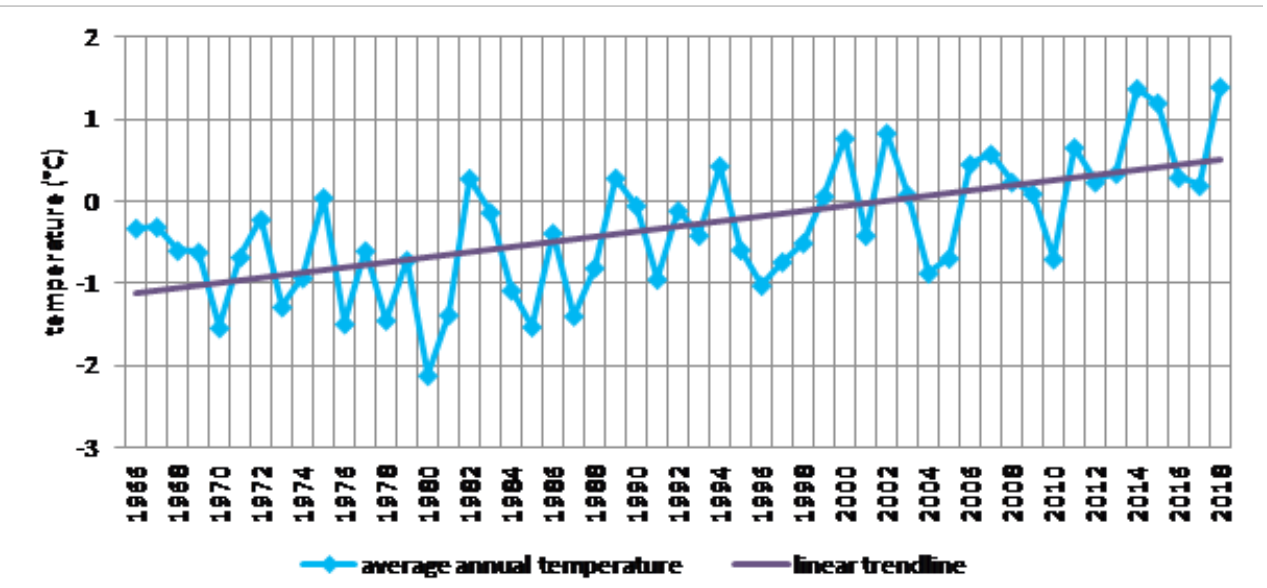

Fig. 2. Average annual temperature in the Kasprovy Wierch meteorological station over 53 years (Kasper peak meteorological station).

from Kasper peak meteorological station (Fig. 2), located $11 \mathrm{~km}$ east from Bystrá peak at an altitude of 1,987 m, to specify the development of the mean annual temperature in the study area. Changes in the values of meteorological elements from this station was analyzed by Czortek et al. (2018), who performed linear regression models using ANOVA to find whether there is a relationship between the year of observation and chosen climate variables (Table 1). According to their results, the mean annual temperature on Kasper peak increased significantly by $1.30^{\circ} \mathrm{C}$ during 
the monitoring period. This increase in temperature was driven by an increase in mean minimum rather than mean maximum annual temperature. The number of days with rain has increased significantly by about 43 days here, and the growing season has extended significantly by about 20 days (Czortek et al., 2018). Study area was intensively grazed by cattle and sheep since the 13th century, which is associated with the period of Wallachian colonization. The damping of pastoral activities in the early 1980s was connected with adding a section of the Western Tatras to the Tatra National Park, while grazing was definitely excluded from the study area in 1986.

Communities of alliance $S$. herbaceae are the first to occupy snow soils. They prefer flat or slightly inclined habitats, which are covered by snow for about 8-10 months during year. Habitats of Festucion picturatae communities are situated on stabilized scree slopes with an inclination of $20^{\circ}-50^{\circ}$, not with long-term snow cover (6.5-7.5 months) (Dúbravcová, 2007). These two floristically poor snowbed communities are most threatened by longer annual snow-free period, resulting from an increase in the mean annual temperature and a decrease in the number of days with snowfall (Carbognani et al., 2014; Pickering et al., 2014; Sandvik, Odland, 2014; Matteodo et al., 2016).

T a b l e 1. Climate changes in the Kasprowy Wierch metorological station (significance level: 0.05*) (Czortek et al., 2018).

\begin{tabular}{|l|c|c|}
\hline Variables & Change & Time period \\
\hline Mean annual temperature & $+1.30^{\circ} \mathrm{C}^{*}$ & $1951-2015$ \\
\hline Max. mean annual temperature & $+1.93^{\circ} \mathrm{C}^{*}$ & $1951-2015$ \\
\hline Min. mean annual temperature & $+2.04^{\circ} \mathrm{C}^{*}$ & $1951-2015$ \\
\hline Number of days with rain & $+43^{*}$ & $1959-2015$ \\
\hline Number of days with snow & -13 & $1959-2015$ \\
\hline Growing season length & $+20^{*}$ & $1951-2015$ \\
\hline
\end{tabular}

\section{Data collection}

The assessment of changes in plant communities was based on a pair comparison of historical and current relevés. In 2016-2018, we resampled historical relevés from 1973 to 1976 (Turečková, 1974; Dúbravcová, 1976), stored in the Central database of phytocoenological relevés (CDF) (Hegedüšová, 2007; Šibík, 2012). Localization of the study sites was based on the header data of historical relevés. If the site conditions did not comply with the localization notes in the headers, we chose the study area at a maximum distance of $50 \mathrm{~m}$ from the probable center of the historical plot. In the case of longer distance, relevés were not resampled.

The methods of Zürich-Montpellier School of Phytosociology (Braun-Blanquet, 1964) were used to study the plant communities. The 7-degree Braun-Blanquet scale was used to estimate the species coverage. Vascular plant nomenclature was modified according to Marhold and Hindák (1998); cryptograms are not included. A major part of the phytocoenological relevés was published in our previous study (Palaj, Kollár, 2017). Our syntaxonomical classification of the studied vegetation follows Jarolímek et al. (2008). For the storage of vegetation data, we used Turboveg (Hennekens, Schaminée, 2001), and for its editing and post-processing, we used the Juice program (Tichý, 2002).

\section{Data analyses}

We use relative frequency change to assess the changes in species composition of snowbed communities. Special emphasis is placed on the frequency and abundance changes of species indicating the grazing to evaluate the effect of cessation of pasture in the 1980s. These indicators are defined by the statistical significance of the relationship between species occurrence/abundance and grazing presence of sites. For determining the level of influence, we use 125 relevés sampled by Horák (1970) who specified the absence/presence of grazing. These data are analyzed using the Indicspecies R package (De Cáceres, Legendre, 2009), and changes in species abundance are tested with t-test.

Shannon-Wiener (SW) (Hill, 1973) and evenness indices (Pielou, 1966) are calculated for all historical and current relevés, and the values are depicted in the box plots using R package reshape2 (Wickham, 2007). Historical and current site conditions are estimated by bioindication using EIV with the Juice software (Tichý, 2002). We focus on the relationship between species and ecological factors, such as light, temperature, continentality, moisture, soil reaction, and nutrients with species abundances included. The box plots (Wickham, 2007) show the results, and the paired t-test was performed using RStudio software (R Core Team, 2017). 
Relevé (dis)similarity is estimated by nMDS indirect ordination methods with the function metaMDS of RStudio Vegan package (Oksanen et al., 2017). Analysis is performed on log-transformed data using Bray-Curtis dissimilarity matrix. We allow the algorithm to ordinate in three dimensions $(\mathrm{k}=3)$ to reduce the stress value equal to or below 0.1, which indicate good results (Hebák et al., 2007). Finally, we use envfit function (Oksanen et al., 2017) to fit environmental factors onto an ordination. The projections of points onto vectors have maximum correlation with corresponding environmental variables, and the factors show the averages of factor levels.

To assess the impact of environmental factors on diversity of communities, we use linear mixed-effect models (Gellman, Hill, 2007; Winter, 2013). Diversity is predicted by fixed effect factors-grazing status of study sites and EIV. As a random effect, we use relevé affiliation to the study sites. The variable "grazing status" includes only the absence and presence of grazing and is determined by the availability of the study site for the livestock. According to Cook (1966), Wilcox and Wood (1988), Crofts and Jefferson (1999), Coldea (2003), Ditsch et al. (2006), Baur et al. (2007), and Catorci et al. (2012), livestock is able to graze only areas with inclination not exceeding $35^{\circ}$. To identify such areas, we created a vector layer from the digital elevation model $(10 \mathrm{~m})$ using QGIS module Terrain Analysis (QGIS Development Team, 2019) and overlapped it with the study site coordinates.

\section{Results}

\section{Changes in phytodiversity}

As a first step, we identified species that we consider to indicate grazing to separate changes triggered by climate change and land use (grazing cessation). These are as follow: Anthoxanthum alpinum, Deschampsia cespitosa, Nardus stricta, Omalotheca supina, and Phleum rhaeticum. Except for Nardus stricta, all of them show decrease in their frequency. In addition, Anthoxanthum alpinum, Deschampsia cespitosa, and Phleum rhaeticum decreased even in their abundance. However, paired t-test at a 0.05 level of significance did not show any statistically significant differences (Table 2).

T a b l e 2. Changes in abundance and frequency of indicator species and results of the paired t-test.

\begin{tabular}{|l|c|c|c|c|c|c|}
\hline Indicator species & $\mathbf{F}_{\mathbf{h}}$ & $\mathbf{F}_{\mathbf{c}}$ & $\mathbf{A}_{\mathbf{h}}$ & $\mathbf{A}_{\mathbf{c}}$ & t-value & p-value \\
\hline Antoxanthum alpinum & 61.90 & 42.86 & 6.08 & 2.22 & 1.644 & 0.116 \\
\hline Deschampsia cespitosa & 19.05 & 9.52 & 2.75 & 2.00 & 1.099 & 0.284 \\
\hline Nardus stricta & 23.81 & 38.10 & 2.20 & 3.38 & -1.099 & 0.285 \\
\hline Omalotheca supina & 23.81 & 9.52 & 14.40 & 20.50 & 0.412 & 0.685 \\
\hline Phleum rhaeticum & 23.81 & 19.05 & 2.40 & 2.25 & 0.413 & 0.684 \\
\hline
\end{tabular}

Notes: $F_{h}-$ frequency in group of historical relevés (\%); $F_{c}-$ frequency in group of current relevés (\%); $A_{h}-$ average non-zero abundance in group of historical relevés (\%); $\mathrm{A}_{\mathrm{c}}$ - average non-zero abundance in group of current relevés (\%).

In summary, we recorded 50 species of vascular plants, while both Turečková (1974) and Dúbravcová (1976) recorded only 45 species. Also phytodiversity parameters such as SW index and equitability show some differences between historical and actual data set (Fig. 3 ). However, these changes are not statistically significant, except for the average number of species per relevé in Salicion herbaceae dataset with its increase from 9.14 to 11.29 (Table 3).

Relevés of Festucion picturatae alliance show distinct decrease in the frequency of the most of alliance diagnostic species, such as Doronicum stiriacum (-80\%), Soldanella carpatica (-80\%), 


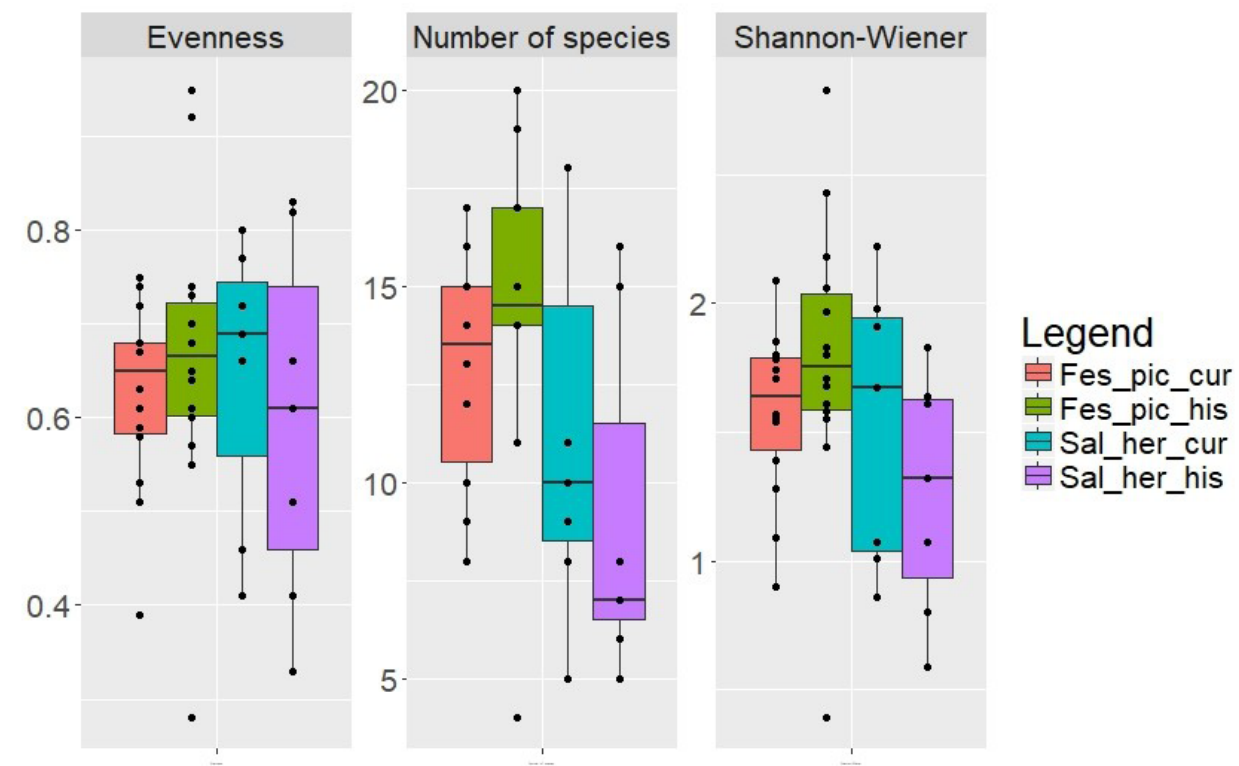

Fig. 3. Comparison of historical and contemporary diversity parameters.

Notes: Fes_pic_cur - current relevés of Festucion picturatae; Fes_pic_his - historical relevés of Festucion picturatae; Sal_her_cur - current relevés of Salicion herbaceae; Sal_her_his - historical relevés of Salicion herbaceae.

$\mathrm{T}$ a b l e 3. Comparison of average values for historical and contemporary site conditions estimated by Ellenberg's eco-indices and results of the paired t-test (significance level: $0.05^{\star}$ ).

\begin{tabular}{|l|c|c|c|c|c|c|c|c|}
\hline \multirow{2}{*}{ Atribute } & \multicolumn{4}{|c|}{ Festucion picturatae } & \multicolumn{4}{c|}{ Salicion herbaceae } \\
\cline { 2 - 10 } & Mean h & Mean c & t-value & p-value & Mean h & Mean c & t-value & p-value \\
\hline Shannon-Wiener & 1.790 & 1.577 & 1.499 & 0.158 & 1.266 & 1.531 & -1.009 & 0.352 \\
\hline Evenness & 0.666 & 0.625 & 0.910 & 0.380 & 0.596 & 0.644 & -0.461 & 0.661 \\
\hline Number of species & 14.643 & 12.786 & 1.738 & 0.106 & 9.143 & 11.286 & $-2.680^{*}$ & 0.037 \\
\hline Light & 7.167 & 6.914 & $2.155^{*}$ & 0.050 & 7.316 & 7.243 & 0.538 & 0.610 \\
\hline Temperature & 2.282 & 2.539 & -1.871 & 0.084 & 1.827 & 2.130 & -1.649 & 0.150 \\
\hline Continentality & 2.919 & 3.021 & -0.912 & 0.379 & 2.941 & 3.133 & -0.802 & 0.453 \\
\hline Moisture & 5.667 & 5.544 & 0.759 & 0.462 & 6.693 & 6.007 & 1.982 & 0.095 \\
\hline Soil reaction & 3.224 & 3.336 & -0.488 & 0.634 & 3.444 & 3.513 & -0.338 & 0.747 \\
\hline Nutrients & 2.816 & 2.832 & -0.086 & 0.933 & 4.217 & 3.701 & 1.557 & 0.171 \\
\hline
\end{tabular}

Ranunculus pseudomontanus (-55.6\%), and Potentilla aurea (-45.5\%) (Fig. 4). These species are replaced by species of adjacent communities, especially by those typical for Caricetea curvulae, Loiseleurio-Vaccinieta, and Nardetea strictae classes (N. stricta [+66.7\%], Vaccinium myrtillus [+28.6\%], Agrostis pyrenaica [+20\%], and Hieracium alpinum [+11.1\%]). Of species indicating grazing, we observed a decrease in the frequency of Omalotheca supina $(-100 \%)$, Phleum rhaeticum (-75\%), Deschampsia cespitosa (-66.7\%), and Anthoxanthum alpinum (-30\%); only 


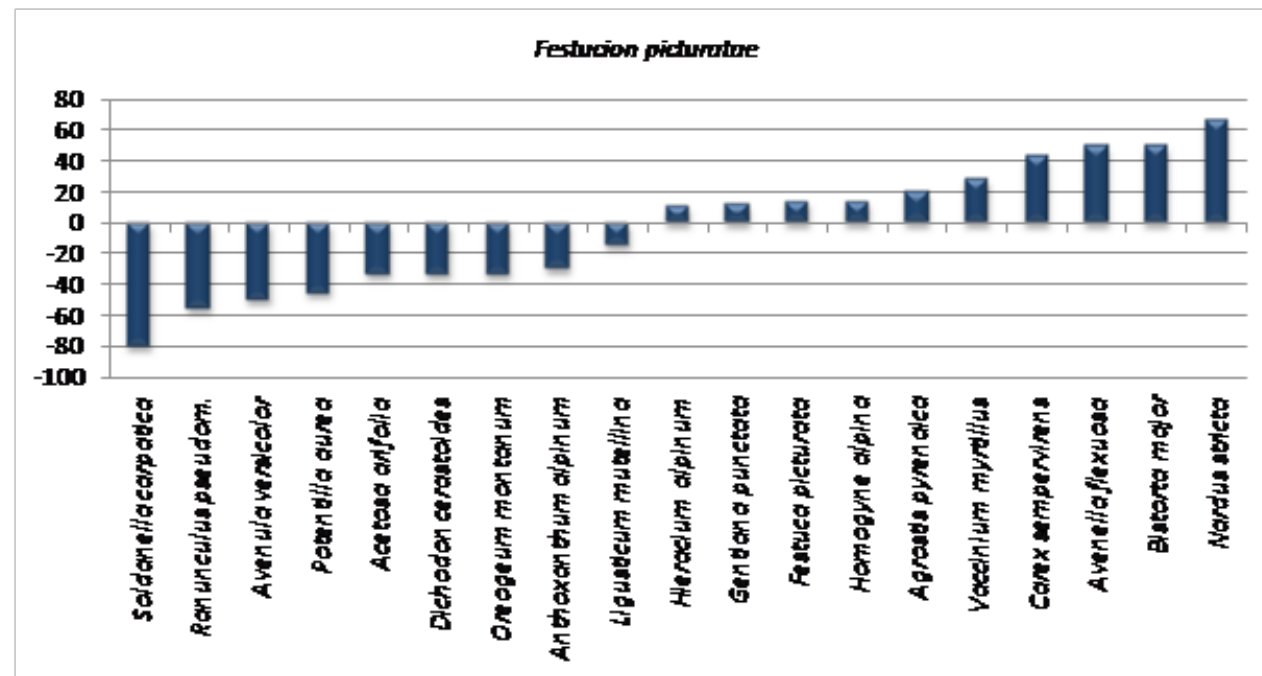

Fig. 4. Relative change of species frequencies of Festucion pictuaratae alliance.

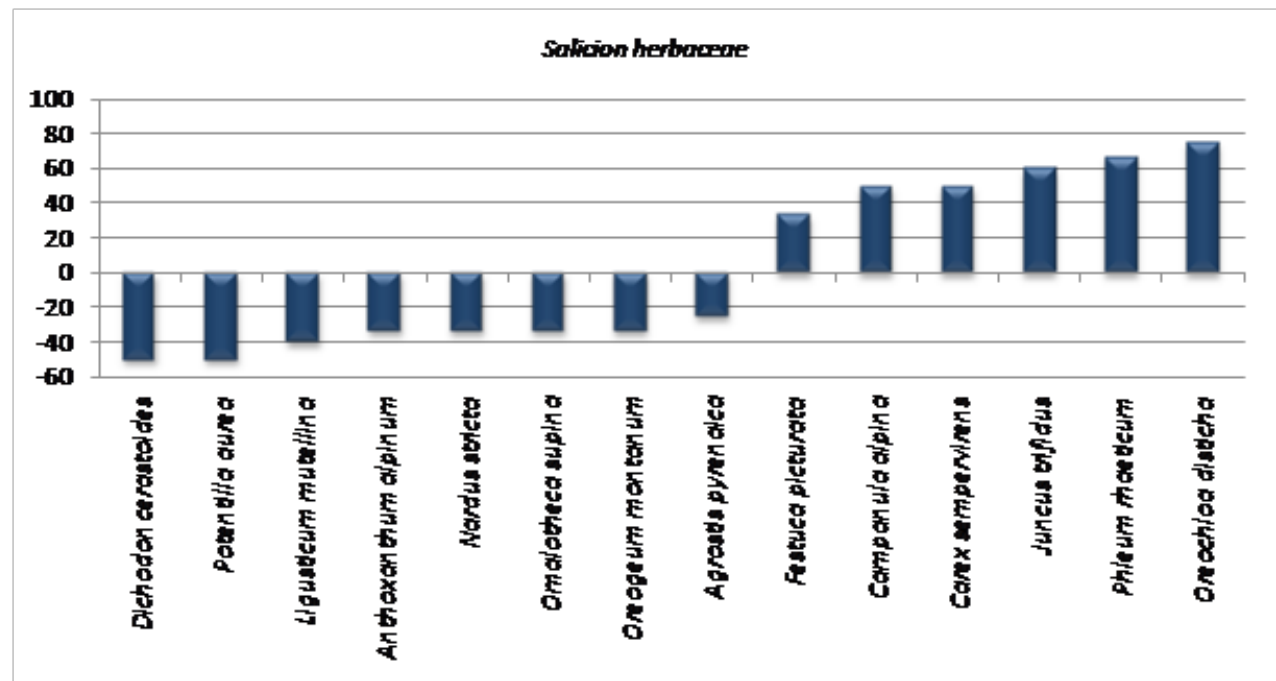

Fig. 5. Relative change of species frequencies of Salicion herbaceae alliance.

Nardus stricta (+66.7\%) showed an increase. Compared to the historical data, we recorded the occurrence of some additional species. These includes some Carpathian endemic species such as Campanula serrata and Cardaminopsis neglecta; endangered species such as Primula minima (EN), Juncus filiformis (LR), Silene acaulis (LR), and Viola lutea ssp. sudetica (LR); and some 
others (Achillea millefolium, Bartsia alpina, Carex nigra, Poa alpina, Pulsatilla scherfelii and Vaccinium gaultherioides). On the contrary, our research did not confirm some endangered species such as Leucanthemopsis alpina (VU) and Rhodiola rosea (VUr), Tatra Mts. endemic Poa granitica, Carpathian subendemic Campanula tatrae and some others, such as Adenostyles alliariae, Calamagrostis villosa, Cerastium fontanum, Omalotheca supina and Sedum alpestre.

Salicion herbaceae alliance shows significant decrease in the frequency of its dominant and characteristic species (Fig. 5), especially Leucanthemopsis alpina (-100\%), Sedum alpestre $(-100 \%)$, Dichodon cerastoides (-50\%), Ligusticum mutellina (-40\%), Omalotheca supina $(-33.3 \%)$, and Oreogeum montanum (-33.3\%). On the other hand, we observed an increase in some species characteristic for Juncion trifidi alliance (Avenella flexuosa [+100\%], Festuca supina [+100\%], Oreochloa disticha [+75\%], Juncus trifidus [+60\%], Campanula alpina [+50\%]) or Luzuletum obscurae association (Homogyne alpina [+100\%] and Festuca picturata $[+33.3 \%])$. Of the grazing indicators, Anthoxanthum alpinum (-33.3\%), Nardus stricta $(-33.3 \%)$, and Omalotheca supina (-33.3\%) decreased in frequency, contrary to Deschampsia cespitosa (+0\%) with no change and Phleum rhaeticum (+66.7\%) with an increase. Our results revealed an increase in the occurrence of some reptile small shrubs, especially those of Vaccinium genus with new occurrence in some plots. Contrary to the historical data, we did not record Tatra Mts. endemic Poa granitica and endangered Leucanthemopsis alpina (VU) and found some new species, including Gentiana punctata (LR) and Primula minima (EN).

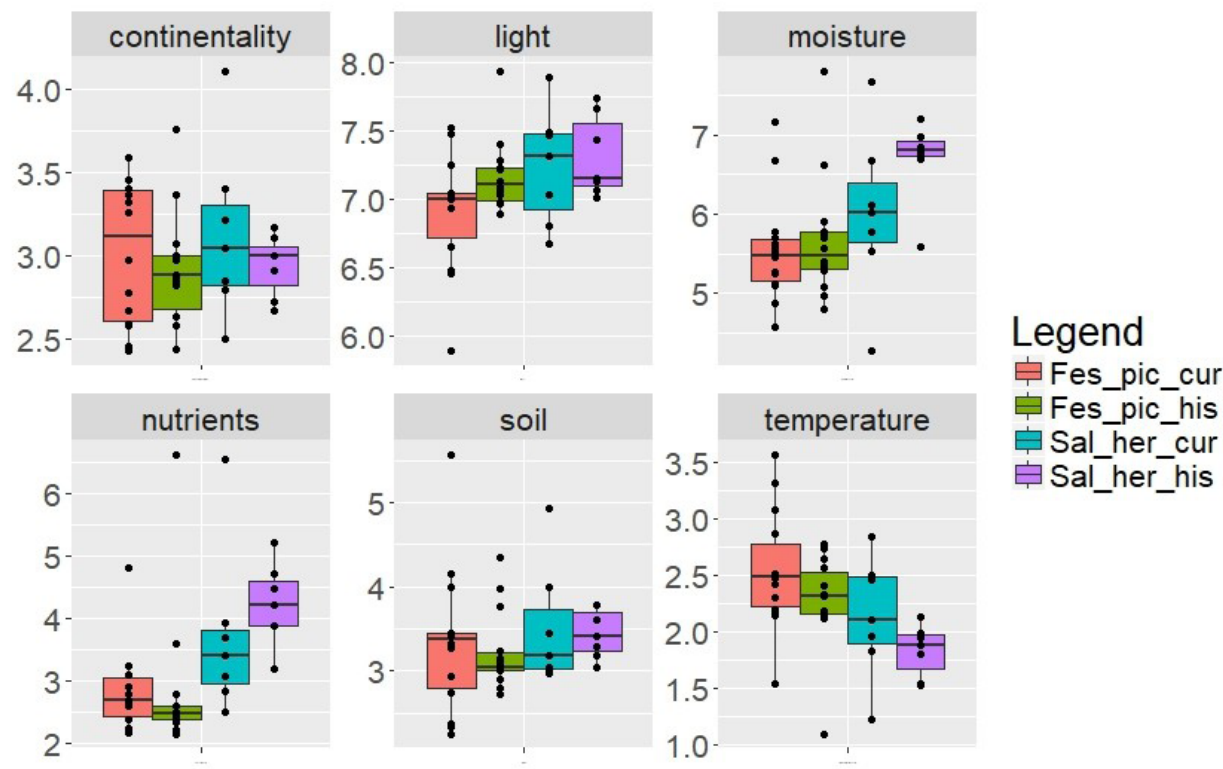

Fig. 6. Comparison of historical and contemporary site conditions estimated by Ellenberg's eco-indices.

Notes: Fes_pic_cur - current relevés of Festucion picturatae; Fes_pic_his - historical relevés of Festucion picturatae; Sal_her_cur - current relevés of Salicion herbaceae; Sal_her_his - historical relevés of Salicion herbaceae. 


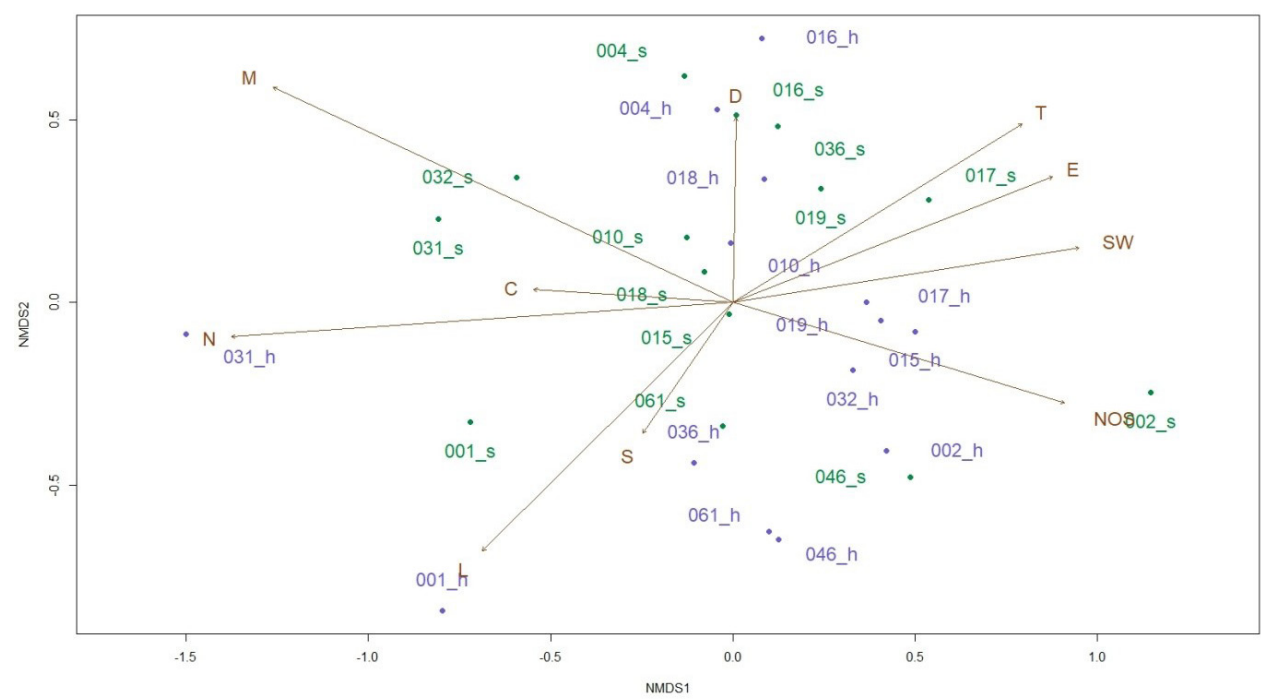

Fig. 7. nMDS ordination diagram $(\mathrm{k}=3)$ showing the distribution of current and historical relevés of Festucion picturatae alliance with fitted environmental factors. Blue colour indicates historical relevés, green indicates current relevés. Notes: sufix _h - historical relevés; sufix _s - current relevés; C - continentality; D - date; L - light; $\mathrm{M}$ - moisture; $\mathrm{N}$ - nutrients; S - soil reaction; T - temperature; E - evenness index; NOS - number of species; SW - ShannonWiener index.

\section{Phytoindicated changes in environment conditions}

Phytoindicated changes in the environment of Festucion picturatae alliance (Fig. 6) include statistically significant increase in the temperature and decrease in light. The average values for light decreased from 7.17 to 6.91 (Table 3). Such shift is caused by the decrease in some light-demanding species (Avenula versicolor, Dichodon cerastoides, Oreochloa disticha, Phleum rhaeticum, Potentilla aurea, Sedum alpestre) and the increase in abundances of some relatively shadow-tolerant species (Avenella flexuosa, Homogyne alpina, Solidago virgaurea subsp. minuta, and Vaccinium myrtillus). Data on Salicion herbaceae alliance revealed some increase in temperature, soil moisture, and soil reaction and decrease in light; however, these changes were not statistically significant by paired t-test.

\section{Ordination plot of historical and recent relevés}

NMDS plot (stress 0.10) shows clustering of two groups of Festucion picturatae relevés, especially along the second axis (Fig. 7). Most of the historical data are on the right side of the biplot, while the current ones are located mostly on the left side. However, except for sites 2, 31,32 , and 36 , relevés of the other sites are mixed on the plot, which suggests small difference in species composition between the two sampling times. On the study site 2 , we recorded a 


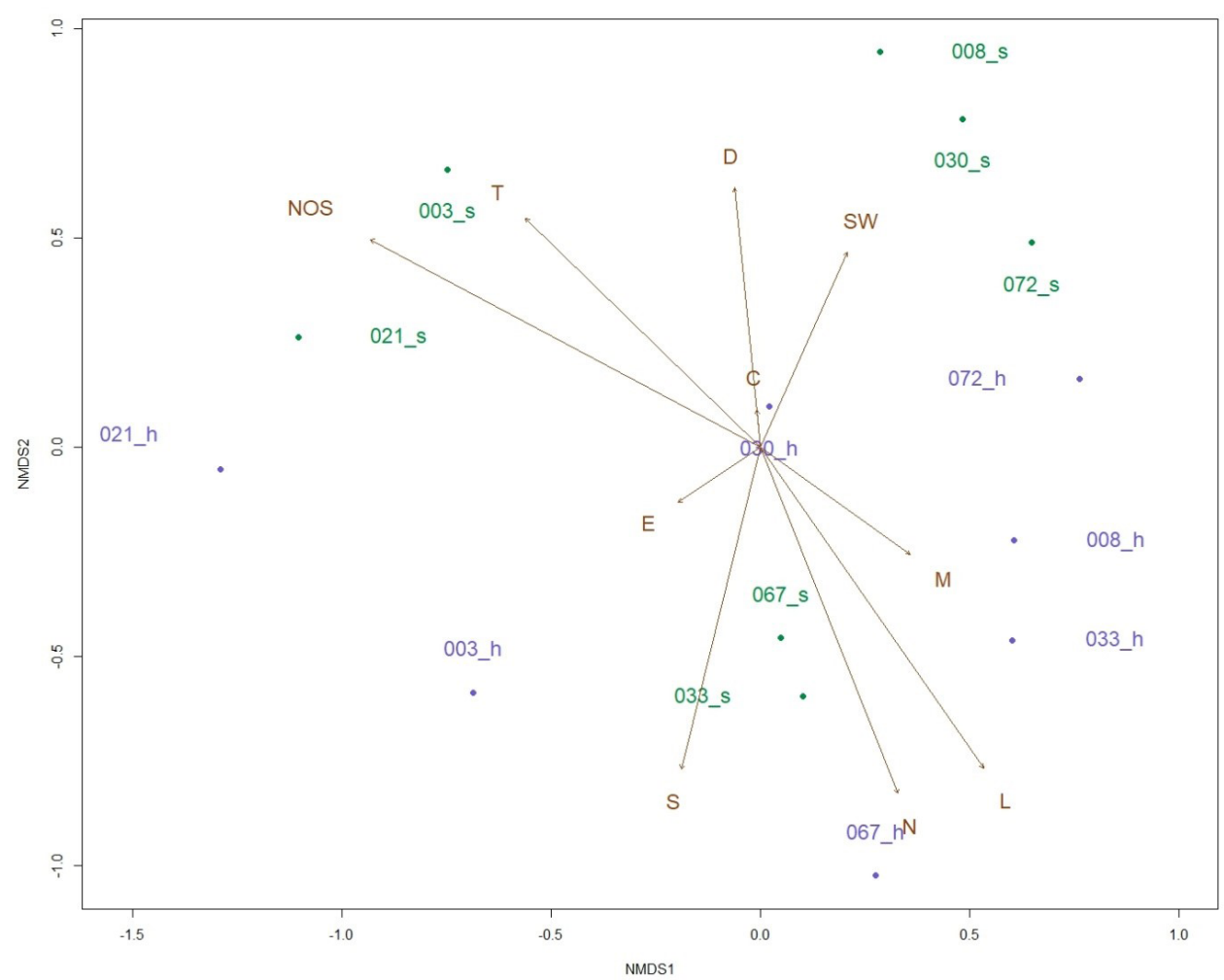

Fig. 8. nMDS ordination diagram $(\mathrm{k}=3)$ showing the distribution of current and historical relevés of Salicion herbaceae alliance with fitted environmental factors. Blue colour indicates historical relevés, green indicates current relevés.

Notes: sufix_h - historical relevés; sufix _s - current relevés; C - continentality; D - date; L - light; $\mathrm{M}$ - moisture; $\mathrm{N}$ - nutrients; S - soil reaction; T - temperature; E - evenness index; NOS - number of species; SW - ShannonWiener index.

relatively high increase in soil nutrient factor (from 2.38 to 2.65); site 31 shows a decrease in light (from 7.94 to 7.52). The differences observed in the species composition of historical and current relevés in sites 36 and 32 are caused by the decrease in the light variable and the decrease in the number of species.

Figure 8 illustrates that nMDS ordination distinctly separated the historical and current relevés of Salicion herbaceae alliance. At the top of the biplot (stress 0.09), current relevés are predominant, while historical ones are mainly situated at the bottom. Almost all relevés are located on the periphery of the ordination diagram, only a historical relevé from the site 30 is situated in the center of the configuration. Sites 3,8 , and 30 show the biggest differences in species composition. Long distances between historical and current relevés in sites 3 and 
T a b l e 4. Results of linear mixed-effect models. SW index is used as a dependent variable. Diversity is predicted by fixed effect factors - grazing status of study sites and EIV. As a random effect is used relevé affiliation to the study site (significance level: $0.05^{\star}$ ).

\begin{tabular}{|c|l|c|c|c|c|}
\hline Alliance & \multicolumn{1}{|c|}{ Factors } & Estimate & Standard Error & t-value & p-value \\
\hline \multirow{5}{*}{ Festucion picturatae } & Light & -0.545 & 0.320 & -1.702 & 0.105 \\
\cline { 2 - 6 } & Temperature & -0.833 & 0.265 & $-3.140^{*}$ & 0.006 \\
\cline { 2 - 6 } & Moisture & 0.128 & 0.182 & 0.702 & 0.491 \\
\cline { 2 - 6 } & Soil reaction & 0.149 & 0.119 & 1.253 & 0.229 \\
\cline { 2 - 6 } & Continentality & 0.462 & 0.196 & $2.356^{*}$ & 0.031 \\
\cline { 2 - 6 } & Nutrients & -0.637 & 0.176 & $-3.624^{*}$ & 0.002 \\
\cline { 2 - 6 } & Pasture & 0.182 & 0.180 & 1.011 & 0.326 \\
\hline \multirow{5}{*}{ Salicion herbaceae } & Light & 0.195 & 2.055 & 0.095 & 0.928 \\
\cline { 2 - 6 } & Temperature & -0.853 & 1.312 & -0.651 & 0.542 \\
\cline { 2 - 6 } & Moisture & 0.060 & 1.569 & 0.038 & 0.971 \\
\cline { 2 - 6 } & Soil reaction & 0.597 & 1.647 & 0.362 & 0.730 \\
\cline { 2 - 6 } & Continentality & -0.719 & 0.660 & -1.088 & 0.318 \\
\cline { 2 - 6 } & Nutrients & -0.787 & 1.336 & -0.589 & 0.577 \\
\cline { 2 - 6 } & Pasture & -0.270 & 0.273 & -0.990 & 0.394 \\
\hline
\end{tabular}

8 follow soil nutrient gradient. We recorded an expansion of nutrient-poor soil species (Juncus trifidus, Oreochloa disticha, and Vaccinium gaultherioides) and a decline in nutrient-rich soil species (Dichodon cerastoides, Ligusticum mutellina, Phleum rhaeticum, Poa alpina, P. granitica, and Veronica alpina) here. Changes in species composition indicate decrease in light and increase in temperature. Distance between historical and current relevé in site 30 is due to the increase in SW index (from 1.57 to 2.20 ) and evenness index (from 0.63 to 0.78 ).

\section{Impact of phytoindicated environment conditions and grazing on the phytodiversity}

According to the results of mixed effect models (Table 4), SW of Festucion picturatae alliance is significantly affected by 3 factors: temperature, continentality, and nutrients. In addition to these, light factor also contributes to the changes in values of SW index. Each increase in the value of light, temperature, and nutrients by one unit decreases the value of SW index. Light affected SW ( $p=0.105)$, lowering it by about $0.545( \pm 0.320$ standard errors); temperature $(\mathrm{p}=0.006)$ decreases it by about 0.833 ( \pm 0.265$)$; and nutrients affected $\mathrm{SW}(\mathrm{p}=0.002)$, lowering it by about $0.637( \pm 0.176)$. This effect is most visible on study site 32 , where we observed an increase in the values of all three variables with a simultaneous decrease in the values of SW index. Probably, the biggest impact from all factors has temperature, whose change in values has the opposite character (increase/decrease) as a change in values of SW index on 11 of 14 sites. The change in temperature is mainly represented by its increase, which is the result of the expansion of thermophilous species on study sites, for example, Achillea millefolium, Bistorta major, Juncus filiformis, and Viola lutea ssp. sudetica.

In the case of the Salicion herbaceae alliance, none of the factors has a statistically significant effect on the SW diversity index. However, the impact of the temperature can be considered quite marked. Each increase in the values of this factor by one unit results in a decrease in the SW 
index values by about $0.85( \pm 1.31)$. Despite the relatively high standard error, this phenomenon is visible on study sites $3,8,21,30$, and 67 . Here we observed an expansion of thermophilous species (Bistorta major, Homogyne alpina, Huperzia selago, Phleum rhaeticum, Senecio subalpinus) and a decline in cold-demanding species (Aagrostis pyrenaica, Dichodon cerastoides, Ligusticum mutellina, Omalotheca supina, Oreogeum montanum, and Sedum alpestre), with a simultaneous decrease in SW index values.

\section{Discussion}

Festucion picturatae communities are considered to be permanent under stable ecological conditions. On the contrary, this vegetation become sensitive with changes, especially those linked to the climate (Carbognani et al., 2014). It complies with our research, which revealed penetration of species from adjacent habitats as did Carbognani et al. (2014) in the Rhaetian Alps. Of these, mainly species of Calamagrostion villosae alliance occur as Dúbravcová (2007) expected for the Tatra Mts. as well as Nardus stricta.

Its obvious increase in the frequency does not comply with natural evolution accompanied by its decrease in the area with grazing reduction or cessation (Austrheim et al., 2007; Speed et al., 2014; Korzeniak, 2016). Owing to the significant decrease in other species indicating grazing ( $A n$ thoxanthum alpinum, Deschampsia cespitosa, Omalotheca supina, and Phleum rhaeticum) along with an increase in diagnostic species of Nardion strictae alliance (Carex sempervirens, Agrostis rupestris, Gentiana punctata, and Hieracium alpinum), it can be assumed that the increase in Nardus stricta is a result of climate change.

Good adaptability of $N$. stricta to the increased temperature is also evidenced by the simulation of climate change in Harz Mts. (Bruelhide, 2003). Increased frequency of N. stricta was also reported by Kanka et al. (2011), Kollár et al. (2016), and Matteodo et al. (2016), who as well as Kudernatsch et al. (2005), Pauli et al. (2007), Holzinger et al. (2008), Britton et al. (2009), Vittoz et al. (2009), Odland et al. (2010), Erschbamer et al. (2011), Stöckli et al. (2011), Pickering et al. (2014), and Sandvik, Odland (2014) confirmed the increase in species of alpine communities with the increase in temperature. This is, in compliance with Norton et al. (2009), in conflict with our findings.

Despite these changes, both historical and current physiognomy is determined by same dominant species, such as Festuca picturata and Luzula alpinopilosa ssp. obscura with no obvious changes in the frequency and abundance. This is also confirmed by nMDS ordination, which showed similarity in relevés from both periods. Besides the above-mentioned reasons, differences were observed for less-abundant species such as decrease in light-demanding species (Avenula versicolor, Dichodon cerastoides, Potentilla aurea, and Soldanella carpatica) and increase in relatively thermophilous species (Bistorta major, Homogyne alpina, and Juncus filiformis), and reptile small shrubs (Vaccinium gaultherioides and V. myrtillus). Generally, increase in small shrub in snowbeds is assigned to shortened period with snow cover and prolongation of vegetation period (Klanderud, Birks 2003; Cannone et al., 2007; Elmendorf et al., 2012; Grytes et al., 2014; Vanneste et al., 2017).

Communities of Salicion herbaceae alliance are, as those of Festucion picturatae, also sensitive to climate conditions (Carbognani et al., 2014). They are made of chinophilous species with optima in sites covered by snow for about 8-10 months (Krajina, 1933). Gradual truncation of snow cover thickness and lasting in the European alpine landscape, including Tatra Mts. (Czortek et al., 
2018), has a crucial impact on the disappearance of snowbeds and their species (Pauli et al., 2007; Kobiv, 2017, 2018). Decline or even loss of such species, for example, Dichodon cerastoides and Veronica alpina, was also reported in the Romanian Carpathians (Micu, 2009).

In addition, also relatively hygrophilous species follow this trend, because precipitation in the summer decreased in the past decade, despite its annual amount increased (Čepčeková, 2013). This phenomenon was also observed in the Carpathians in Ukraine (Balabukh, Lukianets, 2015; Kobiv, 2018) and, along with temperature increase and associated higher evaporation, it causes decrease in some relatively hygrophilous species (Juncus filiformis, Omalotheca supina, Poa granitica, and Sedum alpestre). Most of the study sites are dominated by Salix herbacea. We observed significant decrease in its abundance. This reptile small shrub is adapted to the short vegetation period and drops leaves in the break of August and September.

However, because of the climate change, temperature stays relatively high in this period. This prolonged vegetation period promotes some strong competitors (Kobiv, 2018). Of these, we observed increase in frequency of Festuca picturata and abundance of Luzula alpinopilosa. Partly, it confirms the assumption that communities dominated by $S$. herbacea are changing into the Festuca picturatae communities (Dúbravcová, 2007). In addition, we recorded significant increase in Vaccinium species, also assigned to the truncation of period with snow cover and prolongation of vegetation period (Klanderud, Birks, 2003; Cannone et al., 2007; Elmendorf et al., 2012; Grytes et al., 2014; Vanneste et al., 2017).

The most distinct difference between changes in the observed alliances is in the change in some diversity parameters. An increase in number of species recorded in Salix herbaceae is assigned to the penetration of eurytopic species and the decrease in ecological specialists (Jurasinski, Kreyling, 2007; Britton et al., 2009; Ross et al., 2012; Carbognani et al., 2014). Thus, this vegetation resembles alpine grasslands much more than 50 years ago (Matteodo et al., 2016). On the other hand, Festuca picturatae alliance shows a decrease in the average number of species per relevé and SW index as well as increase in temperature according to the EIV.

As suggested by Matteodo et al. (2016), these changes may be a result of (1) real loss of species on the sites in time; (2) more precise historical sampling than that of recent; and (3) inaccurate localization of historical sites. The last reason can be omitted, as did Matteodo et al. (2016), because same trend was observed in almost all the study sites. The second one is associated with rare species, not for those we found to significantly decrease in the numerous sites (Anthoxanthum alpinum, Avenula versicolor, Campanula alpina, Cerastium fontanum, Phleum rhaeticum, Ranunculus pseudomontanus, Soldanella carpatica, and Sedum alpestre).

Therefore, the decrease in diversity parameters on the Festucion picturatae sites is probably caused by the denser coverage of plants compared to Salicion herbaceae communities. Windmaißer and Reisch (2013) reported that such vegetation structure leads to the competition of light and soil resources; thus, the penetration of new species is restrained. Also, according to Olsen and Kladerud (2014), communities poor in species (S. herbaceae) are more predisposed to penetration of new species than the species-rich ones (Festucion picturatae). The decrease in the diversity of $F$. picturatae may be affected also by grazing cessation (Baur et al., 2007; Kucharzyk, Augustyn, 2010; Vassilev et al., 2011) despite its impact on SW index was not found to be statistically significant.

Vegetation of both alliances has some trends in common. We observed a decrease in small species, which were replaced by tall species resulting in lower light income as did Tilman (1988) 
and Sammul et al. (2000). This change in vegetation vertical structure is linked to the expansion of more thermophilous species reported from several European mountains (Klanderud, Birks, 2003; Pauli et al., 2007; Erschbamer et al., 2011; Kyyak et al., 2014). It is assigned to climate warming having impact especially on small cryophilous and chinophilous species (Pauli et al., 2007; Micu, 2009; Kobiv 2017).

Their decline is caused not only by the increase in temperature leading to overheating of plant tissues (Dahl, 1998; Kobiv, 2018) but also by strong competitors such as grasses and small reptile shrubs from lower altitudes or adjacent habitats (Abeli et al., 2012). Common phenomenon for both snowbed vegetation types is also the increase in relatively xerophilous species, which results from shorter period with snow cover. It is in compliance with the findings from Daniëls et al. (2011), Carbognani et al. (2014), Balabukh, Lukianets (2015), Czortek et al. (2018), and Kobiv (2018).

Changes in alpine vegetation are induced also by grazing cessation. Similar to climate warming, it promotes the growth of small reptile shrubs and competitive grasses, which results in denser vegetation coverage and suppressing of small species (Pakeman, 2004; Kobiv, 2014; Kyyak et al., 2014). Expansion of Avenella flexuosa results from the synergistic effect of both grazing reduction/cessation (Pakeman, 2004) and temperature increase (Press et al., 1998; Patsias, Bruelheide, 2013). Its significant expansion, sometimes lasting only limited period (Hulme et al., 1999; Velev, Apostolova, 2008), was observed also in the former pastures of northern Wales (Hill et al., 1992), Polish part of Krkonoše Mts. (Fabiszewski, Wojtuń, 2001), Norway region of Setesdal Vesthei (Austrheim et al., 2007; Speed et al., 2014), and Polish part of Tatra Mts. (Korzeniak, 2016).

\section{Acknowledgements}

This study was supported by the Slovak Agency for Science (VEGA) grant 2/0132/18.

\section{References}

Abeli, T., Rossi, G., Gentili, R., Mondoni, A. \& Cristofanelli P. (2012). Response of alpine plant flower production to temperature and snow cover fluctuation at the species range boundary. Plant Ecol., 213, 1-13. DOI: 10.1007/ s11258-011-0001-5.

Austrheim, G., Mysterud, A., Hassel, K., Evju, M. \& Okland R.H. (2007). Interactions between sheep, rodents, graminoids, and bryophytes in an oceanic alpine ecosystem of low productivity. Ecoscience, 14, 178-187. DOI:10.2980/1195-6860(2007)14[178:IBSRGA]2.0.CO ;2.

Balabukh, V.O. \& Lukianets O.I. (2015). Zmina klimatu ta yoho naslidky u Rakhivskomu rayoni Zakarpatskoyi oblasti. Hydrol. Hydrochem. Hydroecol., 37, 132-148.

Baur, B., Cremene, C., Groza, G., Schileyko, A.A., Baur, A. \& Erhardt A. (2007). Intensified grazing affects endemic plant and gastropod diversity in alpine grasslands of the Southern Carpathian mountains (Romania). Biologia (Bratislava), 62, 438-445. DOI: 10.2478/s11756-007-0086-4.

Bohuš, I. (1966). History of Liptov Tatras (in Slovak). Tatranská Lomnica: ŠL Tanap-u.

Braun-Blanquet, J. (1964). Pflanzensoziologie. Grundzüge der Vegetationskunde. Wien \& New York: Springer Verlag.

Britton, A.J., Beale, C.M., Towers, W. \& Hewison R.L. (2009). Biodiversity gains and losses: evidence for homogenisation of Scottish alpine vegetation. Biol. Conserv., 142, 1728-1739. DOI: 10.1016/j.biocon.2009.03.010.

Bruelheide, H. (2003). Translocation of a montane meadow to simulate the potential impact of climate change. Appl. Veg. Sci., 6, 23-24. DOI: 10.1111/j.1654-109X.2003.tb00561.x.

Cannone, N., Sgorbati, S. \& Guglielmin M. (2007). Unexpected impacts of climate change on alpine vegetation. Frontiers in Ecology and the Environment, 5, 360-364. DOI : 10.1890/1540-9295(2007)5[360:UIOCCO ]2.0.CO ;2.

Carbognani, M., Tomaselli, M. \& Patraglia A. (2014). Current vegetation changes in an alpine late snowbed community in the south-eastern Alps (N-Italy). Alpine Botany, 124, 105-113. DOI: 10.1007/s00035-014-0135-x. 
Catorci, A., Gatti, R. \& Cesaretti S. (2012). Effect of sheep and horse grazing on species and functional composition of sub-Mediterranean grasslands. Appl. Veg. Sci., 15, 459-469. DOI: 10.1111/j.1654-109X.2012.01197.x.

Coldea, G. (2003). The alpine flora and vegetation of the southeastern Carpathians. In L. Nagy, G. Grabherr, Ch. Korner \& D.B.A. Thompson (Eds.), Alpine biodiversity in Europe (pp. 65-73). Berlin: Springer-Verlag.

Cook, W. (1966). Factors affecting utilization of mountain slopes by cattle. J. Range Manag., 19, 200-204. DOI: $10.2307 / 3895647$.

Crofts, A. \& Jefferson R.G. (Eds.) (1999). The lowland grassland management. Peterborough: English Nature/The Wildlife Trusts.

Czortek, P., Kapfer, J., Delimat, A., Eycott, A.M., Grytnes, J.-A., Orczewska, A., Ratyńska, H., Zieba, A. \& Jaroszewicz B. (2018). Plant species composition shifts in the Tatra Mts as a response to environmental change: a resurvey study after 90 years. Folia Geobot., 53, 333-348. DOI: 10.1007/s12224-018-9312-9.

Čepčeková, E. (2013). Atmospheric precipitation and storms (in Slovak). In S. Bičárová (Ed.), Observatory of SAS at Skalnaté pleso. 70 years of meteorological measurements (pp. 37-42). Stará Lesná: Geofyzikálny ústav SAV.

Dahl, E. (1998). The phytogeography of Northern Europe: British Isles, Fennoscandia, and Adjacent Areas. Cambridge: Cambridge University Press.

Daniēls, F.J.A., Molenaar, J.G., Chytrý, M. \& Tichý L. (2011). Vegetation change in Southeast Greenland? Tasiilaq revisited after 40 years. Appl. Veg. Sci., 14, 230-241. DOI: 10.1111/j.1654-109X.2010.01107.x.

DeCáceres, M. \& Legendre P. (2009). Associations between species and groups of sites: indices and statistical inference. Ecology, 90, 3566-3574. DOI: 10.1890/08-1823.1.

Ditsch, D.C., Schwab, G., Green, J.D., Johns, J.T., Coleman, R., Hutchens, T. \& Piercy L. (2006). Managing steep terrain for livestock forage production. Lexington: College of Agriculture, University of Kentucky.

Dúbravcová, Z. (1976). Subalpine and alpine vegetation in Kamenistá and Gáborova dolina valleys (Western Tatras) (in Slovak). Msc, PhD thesis, Faculty of Natural Sciences, Comenius University, Bratislava.

Dúbravcová, Z. (2007). Salicetea herbaceae (in Slovak). In J. Kliment \& M. Valachovič (Eds.), Plant communities of Slovakia. 4. Alpine vegetation (pp. 251-282). Bratislava: Veda, vydavatelstvo SAV .

Dye, D.G. (2002). Variability and trends in the annual snow-cover cycle in Northern Hemisphere land areas, 1972-2000. Hydrol. Process., 16, 3065- 3077. DOI: 10.1002/hyp.1089.

Ellenberg, H., Weber, H.E., Dull, R., Wirth, W., Werner, W. \& Paulissen D. (1992). Zeigerwerte von pflanzen in Mitteleuropa. Scripta Geobotanica, 18, 1-258.

Elmendorf, S.C., Henry, G.H.R., Hollister, R.D., Bjork, R.G., Bjorkman, A.D., Callaghan, T.V., Collier, L.S., Cooper, E.J., Cornelissen, J.H.C., Day, T.A., Fosaa, A.M., Gould, W.A., Gretarsdottir, J., Harte, J., Luise, H., Hik, D.S., Hofgaard, A., Jarrad, F., Jonsdottir, I.S., Keuper, F., Klanderud, K., Klein, J.A., Koh, S., Kudo, G., Lang, S.I., Loewen, V., May, J.L., Mercado, J., Michelsen, A., Molau, U., Myers-Smith, I.H., Oberbauer, S.F., Pieper, S., Post, E., Rixen, Ch., Robinson, C.H., Schmidt, N.M., Shaver, G.R., Stenstrom, A., Tolvanen, A., Totland, O., Troxler, T., Wahren, C.-H., Webber, P.J., Welker, J.M. \& Wookey P.A. (2012). Global assessment of experimental climate warming on tundra vegetation: heterogeneity over space and time. Ecol. Lett., 15, 164-175. DOI : 10.1111/j.1461-0248.2011.01716.x.

Elumeeva, T.G., Onipchenko, V.G., Egorov, A.V., Khubiev, A.B., Tekeev, D.K., Soudzilovskaia, N.A. \& Cornelissen J.H.C. ( 2013). Long-term vegetation dynamic in the Northwestern Caucasus: which communities are more affected by upward shifts of plant species? Alpine Botany, 123, 77- 85. DOI: 10.1007/s00035-013-0122-7.

Engler, R., Randin, C.F., Thuiller, W., Dullinger, S., Zimmermann, N.E., Araujo, M.B., Pearman, P.B., Le Lay, G., Piedallu, C., Albert, C.H., Choler, P., Coldea, G., De Lamo, X., Dirnböck, T., Gégout, J.-C., Gómez-García, D., Grytnes, J.-A., Heegaard, E., Høistad, F., Nogués-Bravo, D., Normand, S., Puşcaş, M., Sebastiá, M.-T., Stanisci, A., Theurillat, J.-P., Trivedi, M.R., Vittoz, P. \& Guisan A. (2011). 21st century climate change threatens mountain flora unequally across Europe. Glob. Change Biol., 17, 2330- 2341. DOI: 10.1111/j.1365-2486.2010.02393.x.

Erschbamer, B., Unterluggauer, P., Winkler, E.\& Mallaun M. (2011). Changes in plant species diversity revealed by long-term monitoring on mountain summits in the Dolomites (northern Italy). Preslia, 83, 387-401.

Fabiszewski, J. \& Wojtuń B. (2001). Contemporary floristic changes in the Karkonosze Mts. Acta Soc. Bot. Pol., 70, 237-245. DOI: 10.5586/asbp.2001.031.

Gellman, A. \& Hill J. (2007). Data analysis using regression and multilevel/hierarchical models. Cambridge: Cambridge University Press.

Grytnes, J.-A., Kapfer, J., Jurasinski, G., Birks, H.H., Henriksen, H., Klanderud, K., Odland, A., Ohlson, M., Wipf, S. \& Birks H.J.B. (2014). Identifying the driving factors behind observed elevational range shifts on European mountains. Glob. Ecol. Biogeogr., 23, 876-884. DOI : 10.1111/geb.12170.

Hebák, P., Hustopecký, J., Pecáková, I., Plašil, M., Průša, M., Řezanková, H., Vlach, P. \& Svobodová A. (2007). Multivare statistical methods (3) (in Czech). Praha: Informatorium. 
Hegedüšová, K. (2007). Central database of phytosociological samples (CDF) in Slovakia (in Slovak). Bulletin Slovenskej Botanickej Spoločnosti, 29, 124-129.

Hennekens, S. \& Schaminée J.H.J. (2001). TURBOVEG, a comprehensive data base management system for vegetation data. J.Veg.Sci., 12. 589-591. DOI: 10.2307/3237010.

Hill, M.O. (1973). Diversity and evenness: a unifying notation and its consequences. Ecology, 54, 427-432. DOI: $10.2307 / 1934352$.

Hill, M.O., Evans, D.F. \& Bell S.A. (1992). Long-term effects of excluding sheep from hill pastures in north Wales. J. Ecol., 80, 1-13. DOI: 10.2307/2261058.

Holzinger, B., Hülber, K., Camenisch, M., Grabherr G. (2008). Changes in plant species richness over the last century in the eastern Swiss Alps: elevational gradient, bedrock effects and migration rates. Plant Ecol., 195, 179-196. DOI: 10.1007/s11258-007-9314-9.

Horák, J. (1970). Geobiocoenosis of timber line. Part I. - Western Tatras, Jamnická and Račková dolina valleys (in Czech). Brno: University of Agriculture.

Hulme, P.D., Pakeman, R.J., Torvell, L., Fischer, J.M. \& Gordon I.J. (1999). The effects of controlled sheep grazing on the dynamics of upland Agrostis-Festuca grassland. J. Appl. Ecol., 36, 886-900. DOI: 10.1046/j.1365-2664.1999.00452.x.

Jarolímek, I., Šibík, J., Hegedüšová, K., Janišová, M., Kliment, J., Kučera, P., Majeková, J., Michalková, D., Sadloňová, J., Šibíková, J., Škodová, I., Uhlířová, J., Ujházy, K., Ujházyová, M., Valachovič, M. \& Zaliberová M. (2008). A list of vegetation units of Slovakia. In I. Jarolímek \& J. Šibík (Eds.), Diagnostic, constant and dominant species of higher vegetation units of Slovakia (pp. 295-329). Bratislava: Veda, vydavatel'stvo SAV .

Jurasinski, G. \& Kreyling J. (2007). Upward shift of alpine plants increases floristic similarity of mountain summits. J. Veg. Sci., 18, 711- 718. DOI: 10.1111/j.1654-1103.2007.tb02585.x.

Kanka, R., Barančok, P. \& Krajčí J. (2011). Research of the vascular plants diversity in alpine belt of the Tatry Mts. as a platform for monitoring of the climate changes (in Slovak). Životné Prostredie, 45, 89-92.

Kapfer, J., Virtanen, R. \& Grytnes J.-A. (2012). Changes in arctic vegetation on Jan Mayen Island over 19 and 80 years. J. Veg. Sci., 23, 771- 781. DOI: 10.1111/j.1654-1103.2012.01395.x.

Klanderud, K. \& Birks H. (2003). Recent increases in species richness and shifts in altitudinal distributions of Norwegian mountain plants. Holocene, 13, 1-6. DOI : 10.1191/0959683603hl589ft.

Klein, J.A., Harte, J. \& Zhao X.Q. (2004). Experimental warming causes large and rapid species loss, dampened by simulated grazing, on the Tibetan Plateau. Ecol. Lett., 7, 1170-1179. DOI: 10.1111/j.1461-0248.2004.00677.x.

Kliment, J. \& Valachovič M. (Eds.) (2007). Plant communities of Slovakia. 4. Alpine vegetation (in Slovak). Bratislava: Veda, vydavatel'stvo SAV.

Kobiv, Y. \& Nesteruk Y. (2001). Pedicularis oederi (Scrophulariaceae) in the Chornohora Mts (Ukrainian Carpathians): distribution, biology, ecology and threat. Polish Bot. J., 46, 241-250.

Kobiv, Y. (2014). Response of rare plant species to current changes of vegetation in the Ukrainian Carpathians. Forum Carpaticum 2014: local responses to global challenges (pp. 56-58). Lviv.

Kobiv, Y. (2016). Saxifraga aizoides (Saxifragaceae) in Ukraine. Polish Bot. J., 61, 65-71. DOI: 10.1515/pbj-2016-0004.

Kobiv, Y. (2017). Response of rare alpine plant species to climate change in the Ukrainian Carpathians. Folia Geobot., 52 , 217-226. DOI: 10.1007/s12224-016-9270-Z.

Kobiv, Y. (2018). Trends in population size of rare plant species in the alpine habitats of the Ukrainian Carpathians under climate change. Diversity, 10(3), 62. DOI: 10.3390/d10030062.

Kollár, J., Kanka, R. \& Barančok P. (2016). Sites of the GLORIA Initiative in Slovakia Included into LTER Network (in Slovak). Životné Prostredie, 50, 51-53.

Korzeniak, J. (2016). Mountain Nardus stricta grasslands as a relic of past farming - the effects of grazing abandonment in relation to elevation and spatial scale. Folia Geobot., 51, 93-113. DOI : 10.1007/s12224-016-9246-z.

Krajina, V. (1933). Die Pflanzengesellschaften des Mlynica-Tales in den Vysoké Tatry (Hohe Tatra). Beih. Bot. Centralbl., 51, 774-957.

Kucharzyk, S. \& Augustyn M. (2010). Stability of mountain glades in the Bieszczady National Park (in Polish). Roczniki Bieszczadzkie, 18, 45-58.

Kudernatsch, T., Beck, S., Krenzer, M., Fischer, A., Bernhardt, M., Franz, H., Vogel, M. \& Abs C. (2005). Recent changes in species composition and species richness of alpine grasslands in Berchtesgaden biosphere reserve and national park. 2nd and 3rd GLOCHAMORE workshops (pp. 103-115). L'Aquila.

Kudo, G., Amagai, Y., Hoshino, B. \& Kaneko M. (2011). Invasion of dwarf bamboo into alpine snow-meadows in northern Japan: pattern of expansion and impact on species diversity. Ecology and Evolution, 1, 85- 96. DOI: 10.1002/ece3.9. 
Kyyak, V., Bilonoha, V., Dmytrach, R., Gynda, L., Nesteruk, Y. \& Shtupun V. (2014). Changes in plant population pattern under the natural and man-induced ecosystem transformations of high mountain zone of Ukrainian Carpathians. Forum Carpaticum 2014: local responses to global challenges (pp. 58-60). Lviv.

Marhold, K. \& Hindák F. (Eds.) (1998). Checklist of non-vascular and vascular plants of Slovakia. Bratislava: Veda, vydavatel'stvo SAV.

Matteodo, M., Wipf, S., Stöckli, W., Rixen, C. \& Vittoz P. (2013). Elevation gradient of successful plant traits for colonizing alpine summits under climate change. Environmental Research Letters, 8, 024043. DOI: 10.1088/17489326/8/2/024043.

Matteodo, M., Ammann, K., Verrecchia, E.P. \& Vittoz P. (2016). Snowbeds are more affected than other subalpine-alpine plant communities by climate change in the Swiss Alps. Ecology and Evolution, 6, 6969 - 6982. DOI: 10.1002/ece3.2354.

Micu, D. (2009). Snow pack in the Romanian Carpathians under changing climatic conditions. Meteorology and Atmospheric Physics, 105, 1-16. DOI: 10.1007/s00703-009-0035-6.

Nemčok, J. (1994). Geological bedrock (in Slovak). In I. Vološčuk (Ed.), Tatras National Park. Biosphere Reserve (pp. 14-24). Martin: GRADUS.

Norton, L.R., Murphy, J., Reynolds, B., Marks, S. \& Mackey E.C. (2009). Countryside survey: Scotland results from 2007. Battleby: NERC Centre for Ecology and Hydrology \& The Scottish Government, Scottish Natural Heritage.

Odland, A., Høitomt, T. \& Olsen S.L. (2010). Increasing vascular plant richness on 13 high mountain summits in southern Norway since the early 1970s. Arcti. Antarct. Alp. Res., 42, 458-470. DOI: 10.1657/1938-4246-42.4.458.

Oksanen, J., Guillaume Blanchet, F., Friendly, M., Kindt, R., Legendre, P., McGlinn, D., Minchin, P.R., O'Hara, R.B., Simpson, G.L., Solymos, P., Stevens, M.H.H., Szoecs, E. \& Wagner H. (2017). Vegan: Community ecology package. R package version $2.4-4$.

Olsen, S.L. \& Klanderud K. (2014). Biotic interactions limit species richness in an alpine plant community, especially under experimental warming. Oikos, 123, 71-78. DOI: 10.1111/j.1600-0706.2013.00336.x.

Pakeman, R.J. (2004). Consistency of plant species and trait responses to grazing along a productivity gradient: A multi-site analysis. J. Ecol., 92, 893-905. DOI: 10.1111/j.0022-0477.2004.00928.x.

Palaj, A. \& Kollár J. (2017). Contribution to the knowledge of the alpine vegetation of the Western Tatras (in Slovak). Phytopedon, 16(1), 9-13.

Palaj, A. \& Kollár J. (2018). Changes in alpine vegetation over 50 years in the Western Tatras (Slovakia). Ekológia (Bratislava), 37(2), 122-133. DOI: 10.2478/eko-2018-0012.

Patsias, K. \& Bruelheide H. (2013). Climate change - Bad news for montane forest herb layer species? Acta Oecol., 50, 10-19. DOI: 10.1016/j.actao.2013.02.004.

Pauli, H., Gottfried, M., Reiter, K., Klettner, C. \& Grabherr G. (2007). Signals of range expansions and contractions of vascular plants in the high Alps: observations (1994-2004) at the GLORIA master site Schrankogel, Tyrol, Austria. Global Change Biology, 13, 147-156. DOI: 10.1111/j.1365-2486.2006.01282.x.

Pauli, H., Gottfried, M., Dullinger, S., Abdaladze, O., Akhalkatsi, M., Alonso, J.L.B., Coldea, G., Dick, J., Erschbamer, B., Calzado, F.R., Ghosn, D., Holten, J.I., Kanka, R., Kazakis, G., Kollar, J., Larsson, P., Moiseev, P., Moiseev, D., Molau, U., Mesa, J.M., Nagy, L., Pelino, G., Puşcaş, M., Rossi, G., Stanisci, A., Syverhuset, A.O., Theurillat, J.P., Tomaselli, M., Unterluggauer, P., Villar, L., Vittoz, P. \& Grabherr G. (2012). Recent plant diversity changes on Europe's Mountain Summits. Science, 336(6079), 353-355. DOI : 10.1126/science.1219033.

Pickering, C., Green, K., Barros, A.A. \& Venn S. (2014). A resurvey of late-lying snow patches reveals changes in both species and functional composition across snowmelt zones. Alpine Botany, 124, 93-103. DOI: 10.1007/s00035014-0140-0.

Pielou, E.C. (1966). The measurement of diversity in different types of biological collections. J. Theor. Biol., 13, 131-144. DOI: 10.1016/0022-5193(66)90013-0.

Plesník, P. (1974). Physical geography (in Slovak). In M. Konček (Ed.), Tatras climate (pp. 17-26). Bratislava: Veda, vydavatel'stvo SAV .

Press, M.C., Potter, J.A., Burke, M.J.W., Callaghan, T.V. \& Lee J.A. (1998). Responses of a subarctic dwarf shrub heath community to simulated environmental change. J. Ecol., 86, 315-327. DOI: 10.1046/j.1365-2745.1998.00261.x.

QGIS Development Team (2019). QGIS Geographic Information System. Open Source Geospatial Foundation Project. http://qgis.osgeo.org

R Core Team (2017). R: A language and environment for statistical computing (online). Vienna: R Foundation for Statistical Computing. https://www.gbif.org/tool/81287/r-a-language-and-environment-for-statistical-computing

Ross, L.C., Woodin, S.J., Hester, A.J., Thompson, D.B.A. \& Birks H.J.B. (2012). Biotic homogenization of upland vegetation: patterns and drivers at multiple spatial scales over five decades. J. Veg. Sci., 23, 755-770. DOI: 10.1111/j.1654-1103.2012.01390.x. 
Sammul, M., Kull, K., Oksanen, L. \& Veromann P. (2000). Competition intensity and its importance: results of field experiments with Anthoxanthum odoratum. Oecologia, 125, 18-25. DOI: 10.1007/PL00008887.

Sandvik, S.M. \& Odland A. (2014). Changes in alpine snowbed-wetland vegetation over three decades in northern Norway. Nord. J. Bot., 32, 377- 384. DOI: 10.1111/j.1756-1051.2013.00249.x.

Speed, J.D.M., Martinsen, V., Mysterud, A., Mulder, J., Holand, O. \& Austrheim G. (2014). Long-term increase in aboveground carbon stocks following exclusion of grazers and forest establishment in an alpine ecosystem. Ecosystems, 17, 1138-1150. DOI : 10.1007/s10021-014-9784-2.

Stöckli, V., Wipf, S., Nilsson, C. \& Rixen C. (2011). Using historical plant surveys to track biodiversity on mountain summits. Plant Ecol. Divers, 4, 415- 425. DOI: 10.1080/17550874.2011.651504.

Šibík, J. (2012). Slovak vegetation database. In J. Dengler, J. Oldeland, F. Jansen, M. Chytry, J. Ewald, M. Finckh, F. Glockler, G. Lopez-Gonzalez, R.K. Peet \& J.H.J. Schaminee (Eds.), Vegetation databases for the 21st century. Biodiversity \& Ecology, 4(1), 429-429. DOI : 10.7809/b-e.00216.

Tichý, L. (2002). JUIC E, software for vegetation classification. J. Veg. Sci., 13, 451-453. DOI : 10.1111/j.1654-1103.2002. tb02069.x.

Tilman, D. (1988). Plant strategies and the dynamics and structure of plant communities. Princeton: Princeton University Press.

Turečková, J. (1974). Subalpine and alpine vegetation of Jamnicka dolina valley (Western Tatras) (in Slovak). Diploma work (msc.), Faculty of Natural Sciences, Comenius University, Bratislava.

Vanneste, T., Michelsen, O., Graae, B.J., Kyrkjeeide, M.O., Holien, H., Hassel, K., Lindmo, S., Kapas, R.E. \& De Frenne P. (2017). Impact of climate change on alpine vegetation of mountain summits in Norway. Ecol. Res., 32, 579-593. DOI : $10.1007 /$ s11284-017-1472-1.

Vassilev, K., Pedashenko, H., Nikolov, S.C., Apostolova, I. \& Dengler J. (2011). Effect of land abandonment on the vegetation of upland semi-natural grasslands in the Western Balkan Mts., Bulgaria. Plant Biosyst., 145, 654-665. DOI: 10.1080/11263504.2011.601337.

Velev, N. \& Apostolova I. (2008). Successional changes of Nardus stricta communities in the Central Balkan Range (Bulgaria). Phytol. Balc., 14(1),75-84.

Virtanen, R., Eskelinen, A. \& Gaare E. (2003). Long-term changes in alpine plant communities in Norway and Finland. In L. Nagy, G. Grabherr, Ch. Korner \& D.B.A. Thompson (Eds.), Alpine biodiversity in Europe (pp. 411-422). Berlin: Springer-Verlag.

Vittoz, P., Bodin, J., Ungricht, S., Burga, C. \& Walther G. R. (2008). One century of vegetation change on Isla Persa, a nunatak in the Bernina massif in the Swiss Alps. J. Veg. Sci., 19, 671- 680. DOI: 10.3170/2008-8-18434.

Vittoz, P., Randin, C., Dutoit, A., Bonnet, F. \& Hegg O. (2009). Low impact of climate change on subalpine grasslands in the Swiss Northern Alps. Glob. Change Biol., 15, 209- 220. DOI: 10.1111/j.1365-2486.2008.01707.x.

Weselovska, M. (2009). Changes in meadow vegetation of the Western Tatra Mts and their foreland in the last half century (in Polish). In M. Guzik (Ed.), Long-term changes in nature and management of Tatra National Park (pp. 91-104). Zakopane: Wydawnictwa Tatrzańskiego Parku Narodowego.

Wickham, H. (2007). Reshaping data with the reshape package. Journal of Statistical Software, 21(12), 1-20. http:// www.jstatsoft.org/

Wilcox, B.P. \& Wood K.M. (1988). Hydrologic impacts of sheep grazing on steep slopes in semiarid rangelands. J. Range Manag., 41(4), 303-306. DOI: 10.2307/3899383.

Wilson, S. \& Nilsson C. (2009). Arctic alpine vegetation change over 20 years. Glob. Change Biol., 15, 1676-1684. DOI: 10.1111/j.1365-2486.2009.01896.x.

Windmaißer, T. \& Reisch C. (2013). Long-term study of an alpine grassland: local constancy in times of global change. Alpine Botany, 123, 1- 6. DOI: 10.1007/s00035-013-0112-9.

Winter, B. (2013). Linear models and linear mixed effects models in $R$ with linguistic applications. arXiv:1308.5499. http:// arxiv.org/pdf/1308.5499.pdf 